\title{
Application of the Minor Destructive Test (MDT) method for determination of AAC masonry compressive strength
}

\begin{abstract}
Non-destructive methods (NDT) in masonry made of autoclaved aerated concrete (AAC) are not used as commonly as in concrete or reinforced concrete constructions. The porous structure and sensitivity to atmospheric factors, especially humidity, makes it necessary to determine the compressive strength of the wall in existing and used objects. The article presents a proposal of a semi-non-destructive method for determining the compressive strength of AAC, and then a wall made with thin-layer joints. An empirical curve developed for cellular concrete with nominal density classes 400, 500, 600 and 700 in an air-dry condition was used for calibration. In addition, an empirical relationship was developed to take into account the impact of ABK moisture.
\end{abstract}

Keywords: Minor Destructive Testing; compressive strength; civil engineering structures

\section{Introduction}

The compressive strength of the wall $\mathrm{f}_{\mathrm{k}}$ is the basic quantity that allows checking ULS wall conditions, and consequently, assess the safety of the designed or existing building structure. In contrast to concrete constructions in masonry structures, due to low reliability, non-destructive methods (ultrasonic and sclerometric) are widespread [1]. In in-situ conditions, the compressive strength of the wall can be determined by direct (destructive) method by performing tests using pressure cushions or by retrieving fragments of the wall [2]. The second of the common methods consists of testing small wall samples or components (masonry elements and mortar) and applying appropriate empirical curves to convert the obtained strengths to the sought $f_{k}$ value [3]. In modern walls made with thin-layer joints, in which the mortar plays the role of leveling the unevenness of the supporting surfaces and the butt welds are not filled, determining the compressive strength of the wall requires only the correct determination of compressive strength of the masonry element $f_{B}$ and calculations (using empirical coefficients $\eta_{w}$ i $\delta$ expressing moisture and shape of the sample) of the average normalized compressive strength. Such a procedure allows to apply the recommendations of Eurocode 6 and calculate the characteristic compressive strength of the wall according to the formula:

$$
f_{k}=K f_{b}^{0,85}=K\left(\eta_{\mathrm{w}} \delta f_{\mathrm{B}}\right)^{0,85} \rightarrow K\left(f_{\mathrm{Bw}}\right)^{0,85}
$$

where:

$\mathrm{K}=0.75$ or 0.8 ;

$f_{b}$ - standard normalized compressive strength of the masonry element;

$\mathrm{f}_{\mathrm{Bw}}$ - compressive strength of samples taken from structures taking into account the current humidity.

If the tests are carried out on samples with dimensions other than a $10 \mathrm{~mm}$ cube, the normalized strength shall be determined using $\delta$ coefficients given in PN-EN 772-1 [4]. The standard does not provide conversion factors for non-standard samples, such as cores or micro-cores. Consequently, the calculation of results in advance is burdened with a difficult to estimate mistake. In the literature [5], conversion factors obtained from investigations of other materials such as concrete or ceramics, as well as masonry elements [6] have been known so far. However, relationships dedicated to AAC have not been reported yet. In addition, there are no procedures to determine the characteristic compressive strength of an existing wall with actual density and humidity.

The paper attempts to develop an empirical curve enabling determination of the normalized compressive strength of the wall made of AAC with any density and humidity $\mathrm{f}_{\mathrm{Bw}}$. The general form of the Nevil's curve [5] known from the diagnosis

dr hab. inż. Radosław Jasiński, prof. PŚ; dr hab. inż. Łukasz Drobiec, prof. PŚ; dr inż. Wojciech Mazur - Silesian University of Technology, Poland

Corresponding author. radoslaw.jasinski@polsl.pl 
of ordinary concrete was used, which was calibrated to AAC density classes $(400,500,600$ and 700$)$. Taking into account that in addition to the influence of the process of rising and concentration of mass $[7,8]$, also the moisture content of AAC has a significant impact on compressive strength, tests were performed and additional empirical relationships were built. The analysis was carried out using previously performed tests $[9,10]$ of 494 cylindrical and cuboidal samples, on the basis of which detailed empirical curves were built. This publication is an extension and supplement to the paper presented at the 47th National Conference on Non-destructive Testing [11].

\section{An empirical curve that converts the strength of any sample to strength determined on standard samples in the air-dry state}

If defects such as pores or voids in the material determine the strength of materials, individual samples of different shapes may have a significant dispersion of value. These aspects take into account the statistical theory of Weibull's strength $[12,13]$ according to which, with the same probability of destruction, the strength of a given material depends inversely on the volume of the tested sample:

$$
\frac{\sigma_{1}}{\sigma_{2}}=\left(\frac{V_{2}}{V_{1}}\right)^{1 / m}
$$

where:

$\sigma_{1}, \sigma_{2}$ - stresses which damage samples with volumes $V_{1}$ and $\mathrm{V}_{2}$,

$\mathrm{m}$ - constant.

After taking into account the influence of the slenderness of the samples, the dependence (2) was used by Nevil [5] to form a relationship allowing determination of compressive strength of concrete on samples differing in shape and dimensions from standard samples (cubes $150 \times 150 \times 150 \mathrm{~mm}$ ). The empirical curve used in ordinary concrete has the form:

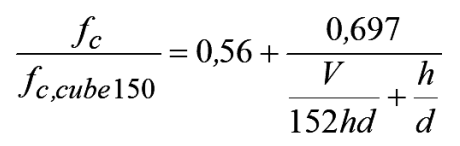

where:

$\mathrm{V}$ - volume of the sample,

$\mathrm{h}$ - height of the sample,

$\mathrm{d}$ - smallest side dimension of the sample.

Assuming in place of the $f_{c, \text { cube } 150}$ strength obtained on standard $150 \times 150 \times 150 \mathrm{~mm}$ samples the strength $\mathrm{f}_{\mathrm{B}}$ obtained on samples from masonry elements $100 \times 100 \times 100 \mathrm{~mm}$, and the quotient $152 \mathrm{hd}$ by the volume of a standard sample 100hd, the relationship (3) can be presented as follows:

$$
\frac{f_{c}}{f_{B}}=b+\frac{a}{\frac{V}{100 h d}+\frac{h}{d}} \rightarrow y=b+\frac{a}{x}
$$

where:

$f_{B}-$ compressive strength of a standard $100 \times 100 \times 100 \mathrm{~mm}$ sample,

$a$ and $b$ - constant curve coefficients,

$y=f_{C} / f_{B}-$ the compression strength quotient determined on a sample of any shape and a standard sample of $100 \times$ $\times 100 \times 100 \mathrm{~mm}$,

$\mathrm{x}=\mathrm{V} / 100 \mathrm{hd}+\mathrm{h} / \mathrm{d}-$ dimensionless coefficient expressing the influence of sample volume and slenderness.
The search for curve parameters (4) was determined by looking for a local minimum sum of squares:

$$
S(a, b)=\sum_{i=1}^{n}\left[y_{i}-y\left(x_{i}\right)\right]^{2}=\sum_{i=1}^{n}\left[y_{i}-\left(\frac{a}{x_{i}}+b\right)\right]^{2}
$$

using dependencies:

$$
\begin{aligned}
& \frac{\partial S(a, b)}{\partial a}=0 \\
& \frac{\partial S(a, b)}{\partial b}=0
\end{aligned}
$$

After differentiating and solving the system of linear equations, the following relationships were obtained in a form facilitating the construction of a correlation table:

$$
\begin{array}{r}
a=\frac{\sum_{i=1}^{n} \frac{y_{i}}{x_{i}}-\frac{1}{n} \sum_{i=1}^{n} y_{i} \sum_{i=1}^{n} \frac{1}{x_{i}}}{\left(\sum_{i=1}^{n} \frac{1}{x_{i}^{2}}-\frac{1}{n} \sum_{i=1}^{n} \frac{1}{x_{i}} \sum_{i=1}^{n} \frac{1}{x_{i}}\right)} \\
b=\frac{1}{n} \sum_{i=1}^{n} y_{i}-\frac{1}{n}\left(\frac{\sum_{i=1}^{n} \frac{y_{i}}{x_{i}}-\frac{1}{n} \sum_{i=1}^{n} y_{i} \sum_{i=1}^{n} \frac{1}{x_{i}}}{\left(\sum_{i=1}^{n} \frac{1}{x_{i}^{2}}-\frac{1}{n} \sum_{i=1}^{n} \frac{1}{x_{i}} \sum_{i=1}^{n} \frac{1}{x_{i}}\right)}\right) \sum_{i=1}^{n} \frac{1}{x_{i}}
\end{array}
$$

When determining the compliance of the curve, it was assumed that uncertainty in $\mathrm{x}$ measurements is neglected (sample geometry). In addition, it was assumed that the uncertainties of all y values were of the same magnitude (usually identical weight of measurements resulting from sampling techniques). To estimate the correlation coefficient the following things were calculated:

- assessment error.

$$
S_{t N}=\frac{1}{n} \sum_{i=1}^{n}\left(y_{i}-y_{m}\right)^{2}
$$

where:

$$
y_{m}=\frac{1}{n} \sum_{i=1}^{n} y_{i}
$$

- sum ot errors:

$$
S_{r N}=\frac{1}{n} \sum_{i=1}^{n}\left(y_{i}-\left(\frac{a}{x_{i}}+b\right)\right)^{2}
$$

and then the correlation coefficient:

$$
r=\sqrt{\frac{S_{t N}-S_{r N}}{S_{t N}}}
$$

Paper [7] presents equations of correlation curves developed for cuboidal and cylindrical samples. The obtained values of the coefficients $a$ and $b$ of the curves are presented in the table I. The comparison of the obtained test results with the common curve is shown in Figure 1.

It should be noted that using a $100 \times 100 \times 100 \mathrm{~mm}$ sample the value of the curve denominator is $V / 100 h d+h / d=2$, and the strength quotients calculated according to the formulas given in Table $I-f_{C} / f_{B} \neq 1$. To obtain a quotient $f_{C} / f_{B}=1$ with standardized samples, the curves should be translated parallel to the abscissae using the additive correction 
factor $\Delta \mathrm{b}$ to form a common curve:

$$
\frac{f_{c}}{f_{B}}=b+\Delta b+\frac{a}{\frac{V}{100 h d}+\frac{h}{d}}
$$

\section{Calibration of the curve}

In place of many curves developed for a given AAC density, for diagnostic purposes, it is much more advantageous to operate such a curve that allows to determine the AAC

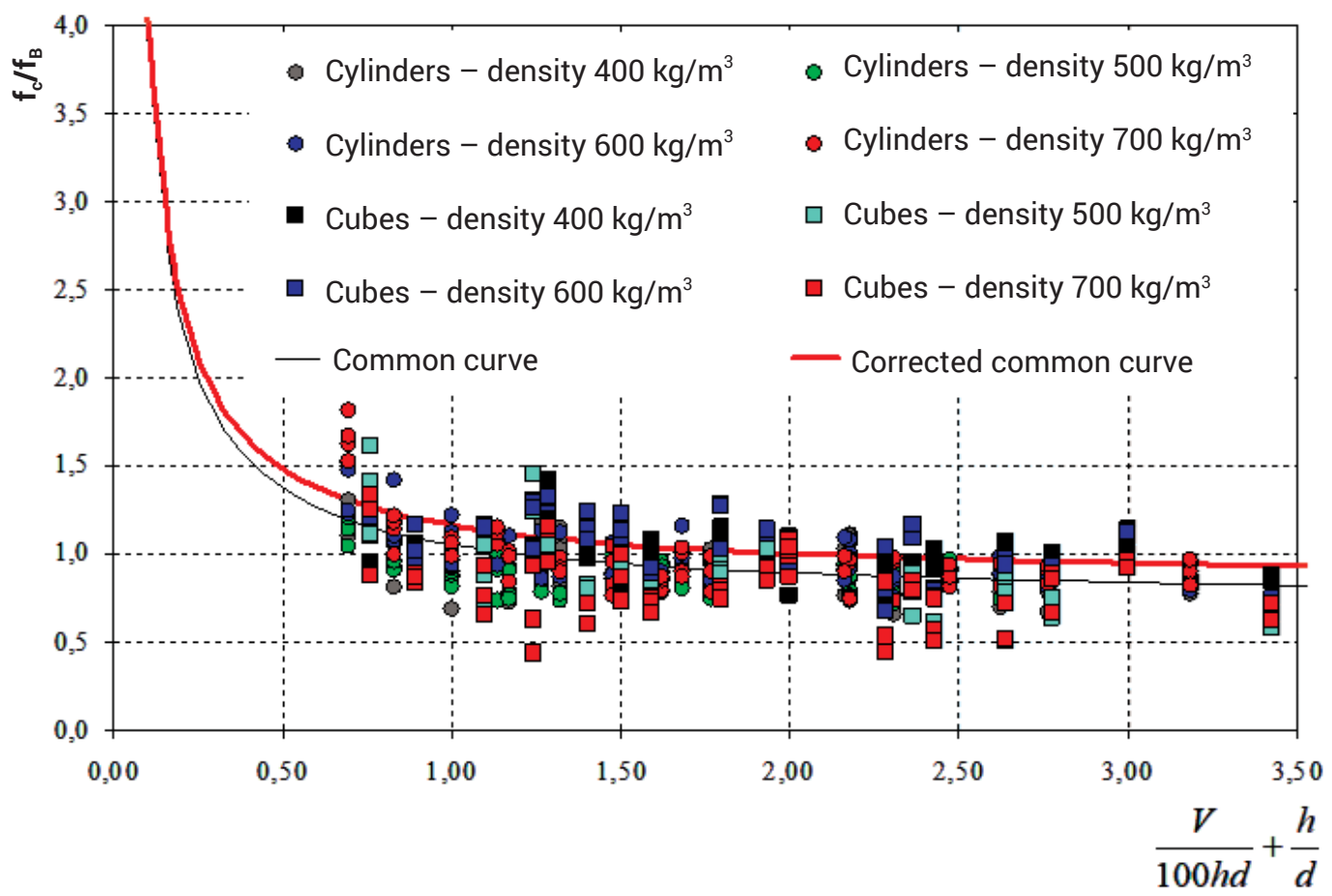

Fig. 1. Test results of all core samples and cubic samples together with the determined correlation curve

Table I. Comparison of coefficients and equations of empirical curves

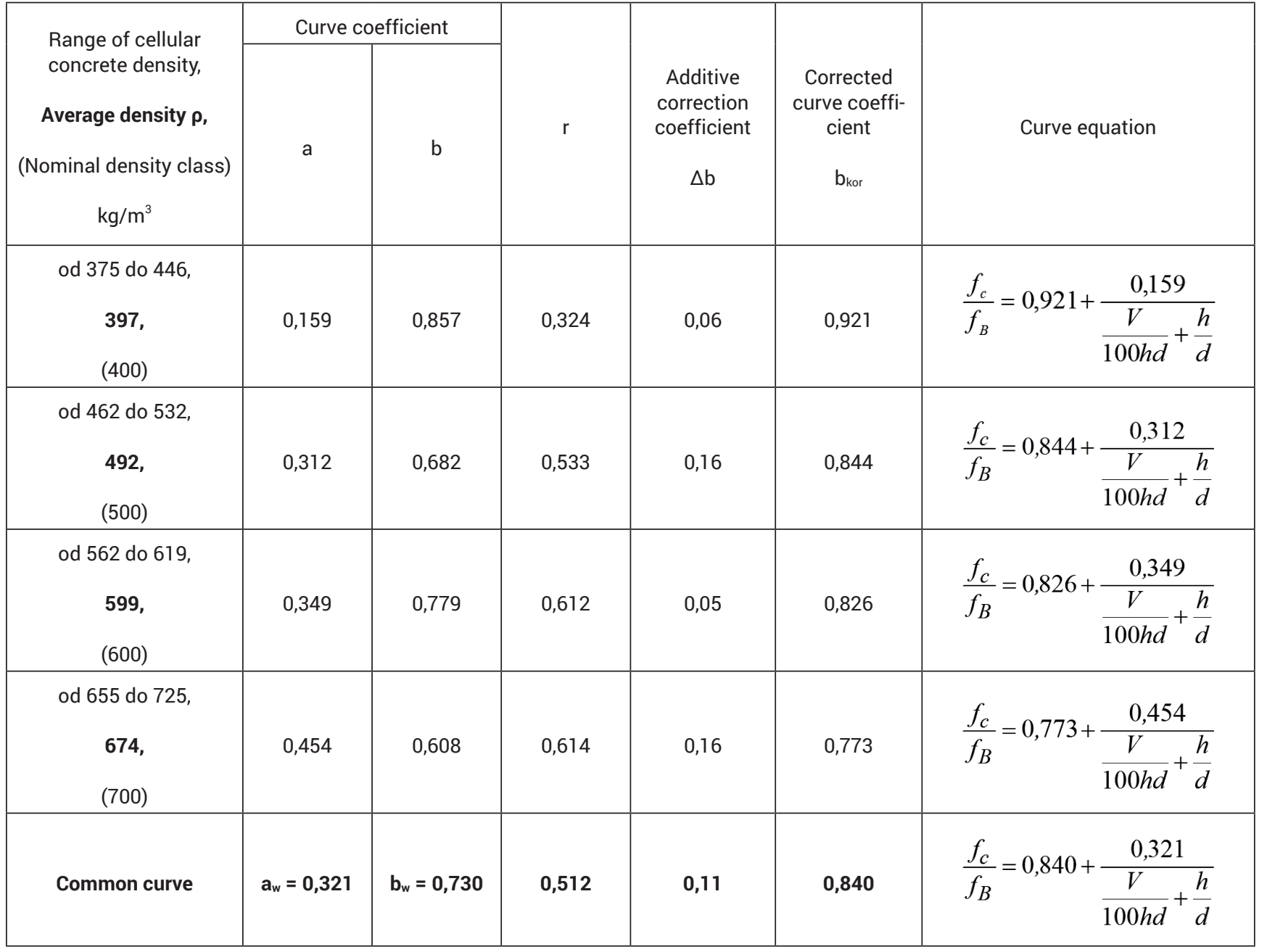


strength of any density and any humidity. Using the values of coefficients $a$ and $b$ specified in the table I for concrete with densities contained in the given ranges and the coefficients aw and bw of the common curve, the correlation relationships shown in Figure 2 were built.

On the basis of the results presented in Figure 2, the following relations were determined by the method of least squares describing values of curves coefficients as a function of AAC density:

$$
\begin{aligned}
& a=a_{w} \cdot\left(3,044 \cdot 10^{-3} \rho-0,653\right)=0,321 \cdot\left(3,044 \cdot 10^{-3} \rho-0,653\right) \\
& b=b_{w} \cdot\left(9,09 \cdot 10^{-4} \rho-1,49\right)=-0,730 \cdot\left(9,09 \cdot 10^{-4} \rho-1,49\right)
\end{aligned}
$$

Of course, after determining the values of $a$ and $b$ and entering them into dependence (13) it is necessary to apply the correction of the coefficient $b$ in order to get $f_{C} / f_{B} \neq 1$ at $\mathrm{V} / 100 \mathrm{hd}+\mathrm{h} / \mathrm{d}=2$.

In addition to the influence of the shape and density of the samples, the influence of the humidity of AAC, which is the quotient of absorbed water relative to the weight of the dry material, was also taken into account:

$$
w=\frac{m_{w}-m_{s}}{m_{s}} \cdot 100 \%
$$

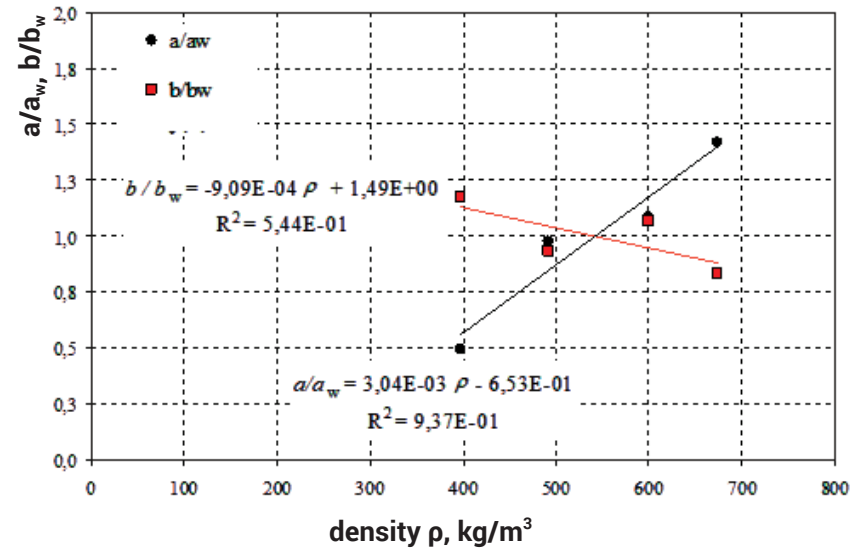

Fig. 2. Relative values of curves coefficients

where:

$\mathrm{m}_{\mathrm{w}}$ - mass of the humid sample,

$\mathrm{m}_{\mathrm{s}}$ - mass of dried sample to constant mass.

The maximum humidity of AAC (moisture absorption) $\mathrm{W}_{\max }$ corresponded to that of water saturation, in which no further increase in mass mw due to capillary rise was observed. The relative humidity was calculated as the quotient

\begin{tabular}{|c|c|c|c|c|c|}
\hline Lp. & $\begin{array}{c}\text { Range of cellular concrete density, } \\
\text { Average density } \boldsymbol{\rho}, \\
\text { (Nominal density class) } \mathrm{kg} / \mathrm{m}^{3}\end{array}$ & $\begin{array}{l}\text { Average humidity } \\
\text { w, \% }\end{array}$ & $\begin{array}{l}\text { Average relative } \\
\text { humidity } \\
\mathrm{w} / \mathrm{w}_{\max }\end{array}$ & $\begin{array}{c}\text { Average } \\
\text { compressive } \\
\text { strength } \\
\mathrm{f}_{\mathrm{Bw}^{\prime}} \mathrm{N} / \mathrm{mm}^{2}\end{array}$ & $\begin{array}{c}\text { Average relative } \\
\text { compressive } \\
\text { strength } \\
\mathrm{f}_{\mathrm{Bw}} / \mathrm{f}_{\mathrm{B}}\end{array}$ \\
\hline 1 & \multirow{6}{*}{$\begin{array}{c}\text { od } 375 \text { do } 446, \\
397 \\
(400)\end{array}$} & 0 & 0 & 2,90 & 1,0 \\
\hline 2 & & 8,3 & 0,10 & 2,64 & 0,92 \\
\hline 3 & & 20,1 & 0,23 & 2,09 & 0,72 \\
\hline 4 & & 29,1 & 0,33 & 2,18 & 0,76 \\
\hline 5 & & 58,3 & 0,67 & 1,96 & 0,68 \\
\hline 6 & & 89,9 & 1,00 & 1,78 & 0,62 \\
\hline 7 & \multirow{6}{*}{$\begin{array}{c}\text { od } 462 \text { do } 532 \text {, } \\
492 \\
(500)\end{array}$} & 0 & 0 & 3,60 & 1,0 \\
\hline 8 & & 6,2 & 0,10 & 3,00 & 0,84 \\
\hline 9 & & 16,2 & 0,23 & 2,44 & 0,68 \\
\hline 10 & & 22,8 & 0,33 & 2,12 & 0,59 \\
\hline 11 & & 46,1 & 0,67 & 2,06 & 0,57 \\
\hline 12 & & 66,0 & 1,00 & 2,24 & 0,62 \\
\hline 13 & \multirow{6}{*}{$\begin{array}{c}\text { od } 562 \text { do } 619, \\
599 \\
(600)\end{array}$} & 0 & 0 & 5,00 & 1,0 \\
\hline 14 & & 5,40 & 0,10 & 4,71 & 0,95 \\
\hline 15 & & 12,6 & 0,23 & 4,21 & 0,85 \\
\hline 16 & & 18,2 & 0,34 & 3,88 & 0,78 \\
\hline 17 & & 58,3 & 0,67 & 1,96 & 0,68 \\
\hline 18 & & 61,1 & 1,00 & 2,82 & 0,57 \\
\hline 19 & \multirow{6}{*}{$\begin{array}{c}\text { od } 655 \text { do } 725 \text {, } \\
674\end{array}$} & 0 & 0 & 5,00 & 1,0 \\
\hline 20 & & 5,30 & 0,10 & 6,86 & 0,85 \\
\hline 21 & & 11,7 & 0,22 & 5,96 & 0,74 \\
\hline 22 & & 16,8 & 0,34 & 5,56 & 0,69 \\
\hline 23 & & 46,1 & 0,67 & 2,06 & 0,57 \\
\hline 24 & & 53,3 & 1,00 & 4,95 & 0,61 \\
\hline
\end{tabular}
of the current humidity and the maximum humidity $\mathrm{w} / \mathrm{w}_{\max }$.

Table II. AAC test results with diversified humidity 
A total of 127 samples $100 \times 100 \times 100 \mathrm{~mm}$, divided into five six-element series, were made of AAC blocks of various densities. Each sample was placed in containers with water in such a way that the water saturation of the samples took place due to capillary rise. Samples were weighed every 6 hours and the humidity was calculated. It was assumed that in the first place maximum humidity will be determined for each type of cellular concrete, and then the samples will be dried in order to achieve the assumed humidity. It was assumed that the strength tests will be conducted at relative humidity of: $\mathrm{w} / \mathrm{w}_{\max }=100 \% ; 67 \% ; 33 \% ; 23 \%, 10 \%$ and $0 \%$. The average test results of individual series of samples are summarized in Table III.

The maximum humidity of cellular concrete depended on the nominal density. It was found that with the density increase from $\rho=397 \mathrm{~kg} / \mathrm{m}^{3}$ to $\rho=674 \mathrm{~kg} / \mathrm{m}^{3}$, the maximum humidity changed in the range of $w_{\max }=89,9 \div 53,3 \%$, which allowed to determine the straight of least squares in the form:

$$
w_{\max }=-1,23 \frac{\rho}{1000}+1,34, \text { gdy } 397 \frac{\mathrm{kg}}{\mathrm{m}^{3}} \leq \rho \leq 674 \frac{\mathrm{kg}}{\mathrm{m}^{3}}
$$

At each humidity, destructive tests were performed determining $f_{B w}$, strength, and the results are shown in Figure $3 a$ as a function of humidity $w$. In Figure $3 b$, the strengths obtained were related to the AAC strength of the completely dry $f B$ and depicted as a function of relative humidity $\mathrm{w} / \mathrm{w}_{\max }$.

Based on the obtained test results, two empirical straight lines were determined which allowed to appoint the relative strength of $A A C$ as a function of relative humidity in the form of:

$$
\begin{aligned}
& \frac{f_{B w}}{f_{B}}=-0,96 \frac{w}{w_{\text {max }}}+1 \rightarrow f_{B w}=f_{B}\left(-0,97 \frac{w}{w_{\text {max }}}+1\right) \text {, gdy } 0 \leq \frac{w}{w_{\text {max }}} \leq 0,31 \\
& \frac{f_{B w}}{f_{B}}=-0,15 \frac{w}{w_{\text {max }}}+0,74 \rightarrow f_{B w}=f_{B}\left(-0,15 \frac{w}{w_{\text {max }}}+0,74\right) \text {, gdy } 0,31<\frac{w}{w_{\text {max }}} \leq 1,0
\end{aligned}
$$
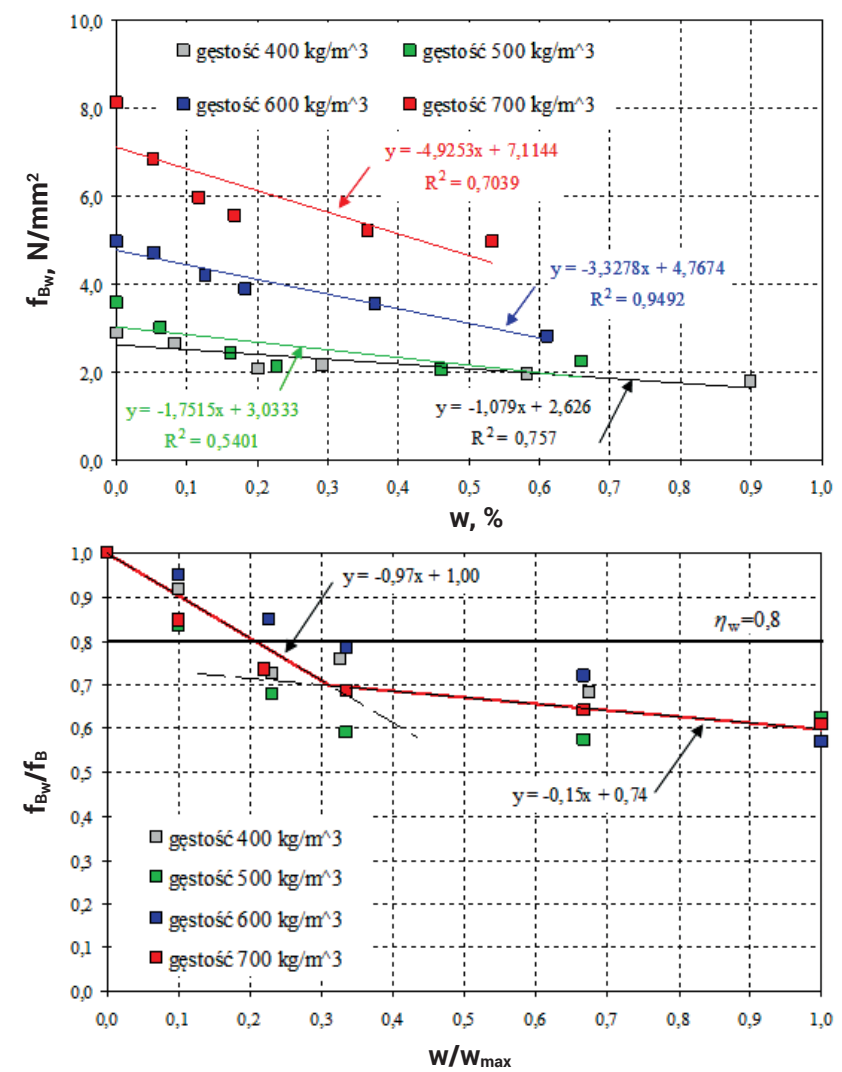

Fig. 3. AAC strength test results including moisture: a) $f_{B w}$ strength as a function of moisture $w, b) A A C f_{B w} / f_{B}$ relative strength as a function of $w / w_{\max }$
The $\mathrm{f}_{\mathrm{BW}}$ strength obtained from the formulas (18) and (19) takes into account the influence of moisture, and thus does not require conversion to the average normalized compressive strength $f_{b}$.

\section{An example of determining the characteristic strength of the wall made of AAC}

The presented considerations were used to determine the characteristic compressive strength of the wall made of AAC with thin-layer welds. The procedure is illustrated by the following example.

The subject of the research was the unplastered wall of a building made of masonry elements from AAC given to environmental impacts over a several-month spring-summer period. Visual inspection showed visible moisture of almost all walls and vertical scratches probably caused by vertical loads resulting from storage of building materials on one of the ceilings. The performed verification calculations showed that with the compressive strength assumed in the design, the load capacity conditions should be met. However, it was suspected that the strength of the material used could be lowered due to strong moisture. The aim of the research was to determine the characteristic strength of the wall for compression. For the needs of the research, 6 cores with a diameter of $50 \mathrm{~mm}$ and a length of $120 \mathrm{~mm}$ were taken from the scratched wall using a diamond lace (Fig. 4). The average humidity of the cores was measured in each place using the weight method according to the formula (16). After transport to the Laboratory, each sample was cut so that the ratio of height to diameter was $h / \varnothing=2$. Then the samples were dried to a constant mass, the apparent density $\rho$ was determined and finally the destructive tests were performed in order to determine the compressive strength $f_{c}$.

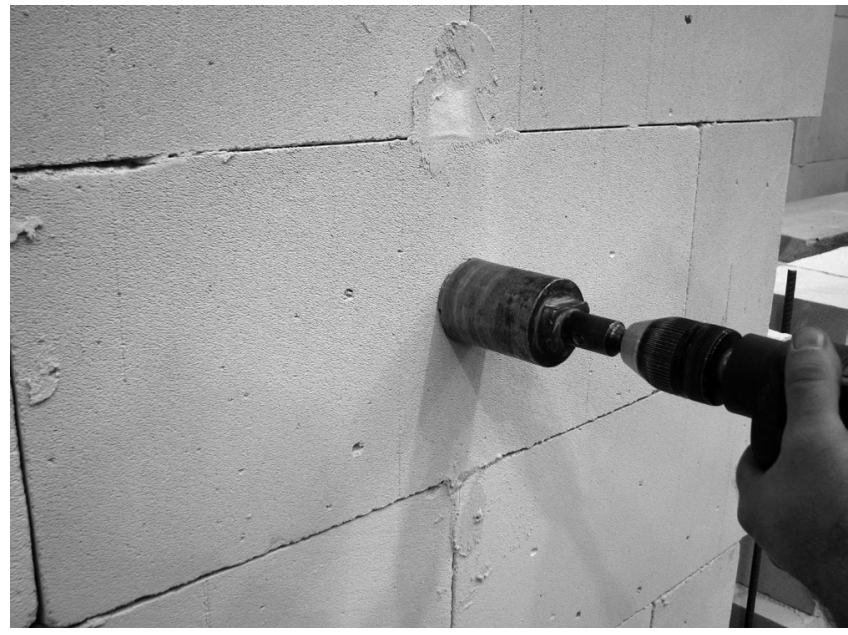

Fig. 4. $A B K$ in-situ tests, collection of core samples

The results obtained are summarized in Table IV. The strength $A A C$ obtained in an air-dry state was $f_{B}=3.59 \mathrm{~N} / \mathrm{mm}^{2}$, and the normalized compressive strength of the element calculated on the basis of formula (1) was $f_{b}=2.87 \mathrm{~N} / \mathrm{mm}^{2}$. In turn, the obtained strength including the influence of moisture which can be treated as the average normalized compressive strength was equal to $f_{B w}=2.41 \mathrm{~N} / \mathrm{mm}^{2}$.

The obtained result shows that the standard coefficient $\eta_{w}=0.8$ too liberally estimates the compressive strength (Fig. $3 b$ ), especially at humidity $w>20 \%$. Eventually, the characteristic compressive strength of the wall obtained 
Table III. AAC test results with diversified moisture

\begin{tabular}{|c|c|c|c|c|c|c|c|c|}
\hline Lp. & $\begin{array}{c}\text { Height of the } \\
\text { sample, } \\
\mathrm{h}, \mathrm{mm}\end{array}$ & $\begin{array}{c}\text { Diameter of } \\
\text { the sample, } \\
\varnothing, \mathrm{mm}\end{array}$ & $\begin{array}{c}\text { Volume of the } \\
\text { sample, } \\
\mathrm{V}, \mathrm{mm}^{3}\end{array}$ & $\begin{array}{c}\text { Density of the } \\
\text { sample, } \mathrm{kg} / \mathrm{m}^{3}\end{array}$ & $\begin{array}{c}\text { Moisture of } \\
\text { the sample } \\
\mathrm{W}, \%\end{array}$ & $\begin{array}{c}\text { Maximum } \\
\text { humidity, } \%\end{array}$ & $\begin{array}{c}\text { Compressive } \\
\text { strength, } \\
\mathrm{f}_{\mathrm{c},} \mathrm{N} / \mathrm{mm}^{2}\end{array}$ & \begin{tabular}{c}
$V$ \\
$\frac{V}{100 h \phi}+\frac{h}{\phi}$ \\
\hline 1
\end{tabular} \\
\hline 101 & 51 & 206325 & 528 & 25 & 69,5 & 4,12 & 2,365 \\
\hline 2 & 102 & 50 & 200277 & 589 & 47 & 62,0 & 3,11 & 2,401 \\
\hline 3 & 99 & 50 & 194389 & 536 & 24 & 68,5 & 3,89 & 2,389 \\
\hline 4 & 101 & 50 & 198313 & 555 & 27 & 66,2 & 3,55 & 2,397 \\
\hline 5 & 100 & 50 & 196350 & 524 & 26 & 70,0 & 3,22 & 2,393 \\
\hline 6 & 98 & 50 & 192423 & 564 & 32 & 65,1 & 3,05 & 2,385 \\
\hline
\end{tabular}

according to the standard dependence and according to own tests were:

$$
\begin{aligned}
& f_{k}=K f_{b}^{0,85}=0,75 \cdot(2,87)^{0,85}=1,84 \mathrm{~N} / \mathrm{mm}^{2} \\
& f_{k}=K f_{b w}^{0,85}=0,75 \cdot(2,39)^{0,85}=1,57 \mathrm{~N} / \mathrm{mm}^{2}
\end{aligned}
$$

Using the standard procedure, the compressive strength of the masonry wall was approx. $17 \%$ greater than by using the proposed empirical curve and the procedure for taking into account the humidity of AAC.

\begin{tabular}{|c|c|c|c|c|c|c|}
\hline Lp. & Coefficient a & Coefficient b & $\begin{array}{c}\text { Correction } \\
\text { coefficient } \\
\Delta \mathrm{b} \\
\end{array}$ & Curve equation & $\begin{array}{c}\text { Strength in dry } \\
\text { condition } \\
\mathrm{f}_{\mathrm{B}}, \mathrm{N} / \mathrm{mm}^{2}\end{array}$ & $\begin{array}{c}\text { Strength in wet con- } \\
\text { dition } \\
f_{\mathrm{Bw}}, \mathrm{N} / \mathrm{mm}^{2}\end{array}$ \\
\hline 1 & 0,306 & 0,737 & 0,11 & $\frac{f_{C}}{f_{B}}=0,737+0,11+\frac{0,306}{\frac{V}{100 h \phi}+\frac{h}{\phi}}$ & 4,22 & 2,33 \\
\hline 2 & 0,366 & 0,697 & 0,12 & $\frac{f_{c}}{f_{B}}=0,697+0,12+\frac{0,366}{\frac{V}{100 h \phi}+\frac{h}{\phi}}$ & 3,21 & 2,01 \\
\hline 3 & 0,314 & 0,732 & 0,11 & $\frac{f_{c}}{f_{B}}=0,732+0,11+\frac{0,314}{\frac{V}{100 h \phi}+\frac{h}{\phi}}$ & 3,99 & 2,74 \\
\hline 4 & 0,333 & 0,719 & 0,11 & $\frac{f_{c}}{f_{B}}=0,719+0,11+\frac{0,333}{\frac{V}{100 h \phi}+\frac{h}{\phi}}$ & 3,65 & 2,48 \\
\hline 5 & 0,302 & 0,740 & 0,10 & $\frac{f_{c}}{f_{B}}=0,740+0,10+\frac{0,302}{\frac{V}{100 h \phi}+\frac{h}{\phi}}$ & 3,30 & 2,26 \\
\hline 6 & 0,341 & 0,713 & 0,12 & $\frac{f_{c}}{f_{B}}=0,713+0,12+\frac{0,341}{\frac{V}{100 h \phi}+\frac{h}{\phi}}$ & 3,14 & 2,09 \\
\hline \multicolumn{5}{|r|}{ Average } & 3,59 & 2,39 \\
\hline
\end{tabular}

Table IV. Results of strength tests of AAC samples

\section{Summary}

The studies have shown that not only the volume and slenderness, but also the moisture content of AAC affects the strength of the material. The largest $30 \%$ reduction in compressive strength in relation to samples dried to constant mass was observed at the humidity of $w=0 \div 30 \%$. Higher humidity caused a reduction in strength by approx. $10 \%$. The use of a standard conversion factor that takes into account the humidity of AAC can give dangerously overstated strength of the wall when it is dank by more than $20 \%$. 


\section{References}

[1] B. A. Suprenant, M. P. Schuller, Nondestructive Evaluation \& Testing of Masonry Structures, Hanley Wood Inc, ISBN 978-0924659577.

[2] R. Orłowicz, P. Tkacz, P. Bilko: Metody badań wytrzymałości muru w budynkach istniejących. XXVI Ogólnopolskie Warsztaty Pracy Projektanta Konstrukcji. Bielsko-Biała-Szczyrk, 9-12.03.(2011), tom II, 163-182.

[3] P. Matysek, Metody określania wytrzymałości murów w konstrukcjach istniejących, XXX Jubileuszowe Ogólnopolskie Warsztaty Pracy Projektanta Konstrukcji. Bielsko-Biała-Szczyrk, 25-28.03.(2015), tom II, 435-462.

[4] PN-EN 771-4:2011 Wymagania dotyczące elementów murowych. Część 4. Elementy murowe $z$ autoklawizowanego betonu komórkowego.

[5] A.M. Neville: Włściwości betonu. 5th edition, Pearson Education Limited (2011), Essex, England.

[6] Ł. Drobiec, R. Jasiński, A. Piekarczyk, Konstrukcje Murowe według Eurokodu 6 i norm związanych. Tom 1, Wydawnictwo Naukowe PWN (2013), Warszawa.

[7] K. Łaskawiec, L. Misiewicz, Deklarowane i uzyskiwane z badań właściwości użytkowe elementów murowych $z$ ABK produkowanych w Polsce,Materiały Budowlane (2014), 11, 46-47.
[8] G. Zapotoczna-Sytek, S. Balkovic, Autklawizowany beton komórkowy. Technologia. Właściwości. Wykonawstwo, Wydawnictwo Naukowe PWN (2013), Warszawa

[9] W. Mazur, $t$. Drobiec, R. Jasiński, Effects of specimen dimensions and shape on compressive strength of specific autoclaved aerated concrete. ICAAC 6th International Conference on Autoclaved Aerated Concrete,Postdam 4-6 september (2018), 541-556, DOI.ORG/10.1002/ cepa.837.

[10] R. Jasiński, Ł. Drobiec, W. Mazur, Validation of selected non-destructive methods for determining the compressive strength of masonry units made of autoclaved aerated concrete, Materials (2019), vol. 12 (3), art no. 389, 1-21.

[11] R. Jasiński, Wyznaczanie wytrzymałości na ściskanie muru z autoklawizowanego betonu komórkowego metodą małoniszczącą, Badania nieniszczące i diagnostyka (2018), 3, 81-85, DOI: 10.26357/BNiD.2018.029.

[12] W. Weibull, A Statistical Theory of Strenght of Materials, Ingvetenskaps Handl (1939).

[13] W. Weibull, A statistical distribution function of wide applicability, Journal of Applied Mechanics (1951), vol.18, 293-297.

(C) 2019 by the authors. Submitted for possible open access publication under the terms and conditions of the Creative Commons Attribution (CC BY) license (http://creativecommons.org/licenses/by/4.0/). 